\title{
How is the implementation of green accounting in public hospital?
}

\author{
Muhammad Hasyim Ashari, ${ }^{1}$ Yudhi Anggoro \\ STIE Indocakti Malang, Indonesia \\ email: muhammadhasyimashari@gmail.com
}

\begin{abstract}
Purpose - The purpose of this study is to find out the implementation of green accounting in Public Hospitals in Malang and to determine the preferences of Public Hospitals in running their business.
\end{abstract}

Method - This research is a descriptive quantitative study conducted by survey method. The total of population are 40 Public Hospitals in Malang Raya and the sample obtained as respondents are 37 Public Hospitals spread across Malang District, Malang City and Batu City. The sample selection used probability sampling by sending a questionnaire to the entire population.

Result - The results showed that the green accounting practices in Public Hospitals in Malang Raya based on financial activities, social activities and environmental activities had been implemented properly and consistently. Public Hospitals with higher types tended to be better and more consistent in applying green accounting than Public Hospitals with lower types (classes).

Implication - With the awareness of Public Hospitals in Malang Raya to implement green accounting in the accountability of their business activities, it can have an impact, especially on environmental sustainability and the welfare of the community around the Public Hospital from the impact of the resulting waste.

Originality - The concept of green accounting can also be implemented to Public Hospitals as a public entity. On this basis, of course, it is necessary to conduct research on the implementation of green accounting in Public Hospitals as a public entity so that in its operational activities it does not only consider the financial aspects to generate profits, but also considers environmental and social aspects. As a result, its business can have an impact especially on environmental sustainability and the welfare of the community around Public Hospitals from the impact of the waste produced.

Keywords: public hospital; green accounting, environment

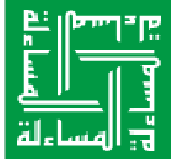


Muhammad Hasyim Ashari, Yudhi Anggoro

\section{Introduction}

A hospital is defined as a health service institution that provides complete individual health services that provide inpatient, outpatient and emergency JIAFR | 132 services. Hospital operational activities, especially Public Hospitals, have the potential to cause problems due to the waste generated because it is the largest type of hazardous waste (Shapiro et al., 2000). The wastes produced are also very complex, starting from liquid waste, medical solid waste, nonmedical solid waste, and gas waste. Therefore, the hospital as a health organization is expected to be responsible for preventing or reducing the bad impacts that can cause damage to the environment and the community around the hospital (Khoirina, 2016). From these efforts, there is an influence on the accounting sector in Indonesia with the emergence of Green Accounting term (Susilo, 2008).

Green Accounting is considered to be more appropriate because it is more fundamental and ecological (Gallhofer \& Haslam, 1997; Greenham, 2010; Thornton, 2013), based on three basic pillars of corporate responsibility, namely economic responsibility, social responsibility, and environmental responsibility (Lako, 2018, Beattie, 2017 and Wibisono, 2007), as in the triple-bottom-line concept that includes profit, people, planet (Elkington, 1997; Porter and Kramer, 2002; Quinn and Baltes, 2007; Dhiman, 2008; Zvezdov, 2012; Hadi, 2014). This is based on the current development of the business world where not only companies are required to pursue economic benefits (profit), companies must also pay attention to and be involved in the welfare of the community (people), and take part in preserving the environment (planet). This is because the environment and society are also part of the stakeholders. With green accounting, it is expected that entities will disclose accounting information related to financial, environmental and social activities that are integrated, comprehensive, and relevant in the form of green accounting reporting which is useful for users in assessments and retrieval of the economic and non-economic decisions. 
The green accounting implementation can provide information about the extent to which organizations (companies) make a positive or negative contribution to the quality of human life and the environment. The implementation of green accounting is expected to improve the company's image that brings stakeholder trust for long-term business sustainability (Setiawan, 2014; Panggabean and Deviarti, 2012), and of course this environmental performance can have a significant effect on the company's financial position (Hansen and Mowen, 2009), improve company performance and value, and reduce company risk (Lako, 2015a, 2015b).

The concept of green accounting can also be implemented to Public Hospitals as a public entity (Deegan, 2003). On this basis, of course, it is necessary to conduct research on the implementation of green accounting in Public Hospitals as a public entity so that in their operational activities, they do not only consider the financial aspects to generate profits, but also consider environmental and social aspects. As a result, their business can have an impact especially on environmental sustainability and the welfare of the community around Public Hospitals from the impact of the waste produced.

This research was conducted at the Public Hospitals (RSU/Rumah Sakit Umum) in Malang Raya with the consideration that hospitals in Malang currently still show an average level of readiness that is currently in environmental problems towards a green hospital (Putri et al., 2016). Based on that, this research was conducted to find out the green accounting implementation at the Public Hospitals in Malang Raya. It is hoped that by green accounting implementation, the environment will be preserved and the existence of the hospital has an impact on the welfare of the community, as well as to find out the preferences of Public Hospitals in Malang Raya which are the main priority in running their business operations. 


\section{Literature Review}

\section{Green Accounting}

JIAFR | 134

Green accounting is a means of reporting a company related to the environment. The goal is to provide information about the company's operational performance based on environmental protection. Conventional accounting only provides economic information that is financial in nature to shareholders and bondholders for decision making. Performance measures need to be increased to improve existing performance measures. Environmental impacts need to be reported as a manifestation of responsibility towards stakeholders (Astuti, 2012).

According to Lako (2016), green accounting is actually a new independent branch of science, which in essence has a much broader meaning than social accounting, environmental accounting, social and environmental accounting, and even sustainable accounting. Its object includes all phenomena, objects, reality, actions, or transactions that are inherent or occur in the universe and human beings. Because the behavior of humans (society) and corporations has a causal relationship with the natural environment, social accounting, financial/economic accounting, and environmental accounting are part of green accounting. Accounting for land, vegetation, forest, water, air, atmosphere, ocean, carbon, waste, social and environmental responsibility of corporate entities, etc. are parts of green accounting.

Conceptually, Lako (2016) defines green accounting as a process of recognizing, measuring value, recording, summarizing, reporting, and disclosing information relating to financial, social and environmental transactions, events and or objects in an integrated manner in the accounting process in order to produce integrated, comprehensive, and relevant accounting information which is useful for users in economic and noneconomic assessment and decision making (Lako, 2016 and 2018: 82). The basic pillars of green accounting information are integrated environmental, social and financial accounting information (Deegan, 2003; Lako, 2018). 
Thus, green accounting is a type of accounting that describes efforts to incorporate environmental and social benefits into economic decision making or a business financial outcome for economic decision making, which is made in a single report package format (Zakiy \& Ramadhan, 2019).

\section{Green Accounting Reporting}

In general, the components of green accounting reports are not much different from the components of financial statements in conventional financial accounting. According to Lako (2018), there are several crucial accounts that distinguish green accounting from conventional (conservative) financial accounting: First, in the asset structure of entities that carry out corporate social and environmental responsibility (TJSLP), CSR, and green activities. The business will appear new accounts such as natural resource assets, social and environmental investments, green investment, or CSR investments under the fixed asset group. In general, the company's asset structure in green accounting construction includes current assets, financial investments, fixed assets, natural resource assets, social and environmental investments, intangible assets, and other assets. Second, in the liability account structure of entities implementing CSR and green corporations, new accounts such as social and environmental liabilities that are contingent will appear. This obligation arises as a logical consequence of management's commitment to the government and society to implement CSR or green business, or to be responsible for the economic losses suffered by the community and the state due to environmental damage or water, air, or land pollution arising from company's operations. The social contingent liabilities and the environmental contingent liabilities are either short-term or longterm depending on the company's commitment to fulfill them. Third, in the structure of the equity accounts of corporate entities that carry out voluntary CSR activities because they are based on the sincere intention and spiritual values of business (CSR) of their shareholders, a new account may appear, namely a CSR donation account, under the income account for the period. The new account emerged because management at the request of the owner or 
shareholder treated a number of CSR programs and sacrifices of the entity's economic resources to carry out CSR as an act of charity or love to fellow people who were poor, weak, disabled, and excluded. Because it is charitable in nature, the information on CSR donations is requested not to be reported to stakeholders and the wider community. The cost of implementing those philanthropic CSR programs is taken from net income or retained earnings which is the property of the shareholders. Because the information is not reported to the public, economically the sacrifices of economic resources for CSR are not considered to bring economic and non-economic benefits in the future. Therefore, from a green accounting perspective, these sacrifices can be recognized, recorded and reported in the CSR Donation account as a deduction from the value of equity. Fourth, in the account structures of production cost and operating costs for entities that carry out CSR, CSR, and green business new cost accounts, such as social costs and environmental costs, or periodic or temporary greening costs, will appear. For example, social assistance costs for natural disasters, waste treatment costs, recycling costs, environmental audit costs, pollution costs, pollution control costs, environmental damage costs, socio-environmental information disclosure costs, and others. In general, the cost structure in the construction of the profit and loss performance report from green accounting includes production costs, operational costs, social and environmental costs and other costs.

\section{Green Accounting Implementation in Public Hospitals}

In practice, green accounting is based on the theory of the three basic pillars of Elkington (1997, 2001), namely: environmental accounting, social accounting and financial accounting. Green accounting is used to report the operations of an institution (country/city/company/organization) related to the environment. The goal is to provide information about the company's operational performance based on protection and concern for the environment (Arizona and Suarjana, 2017). Provision of environmental management information assists management in deciding prices, controlling 
overhead and reporting environmental information to the public (Yakhou and Vernon, 2004).

As one of the operational activities that contribute to a large amount of waste, the hospital needs to make efforts to play an active role in preserving and maintaining environmental health. Therefore the hospital has a role and obligation to preserve the environment by managing waste and implementing good environmental management so that it can be competitive and get a good image from the community as an environmentally friendly institution (Wardah \& Astini, 2018). This action is an effort to preserve the hospital environment to make it better, healthier and more comfortable (Aminah \& Noviani, 2014).

Currently, many hospitals have been implementing green accounting by actively participating in maintaining environmental health (Swastyakso \& Widodo, 2016). Efforts made are not merely manifested in the form of activities, but are also implemented in an accounting system so that they can be implemented in a sustainable manner. To be able to create this condition, the hospital needs information about green accounting. The green accounting implementation in hospital activities is the first step to become a solution to these environmental problems. The green accounting implementation will encourage management's ability to minimize the environmental problems faced. The purpose of applying this accounting is to improve the efficiency of environmental management by assessing environmental activities from the point of view of costs (environmental costs) and benefits or effects (Reller, 2012).

The green accounting implementation is able to provide information regarding physical and monetary, which can help hospitals to make decisions related to the environment based on complete information for decision making (Prasetyo, Indriani \& Widodo, 2020). Burhany (2015) adds that this information can reveal hidden opportunities, such as a better waste management process, a reduction in energy and materials consumption, or an opportunity to recycle materials. 
Muhammad Hasyim Ashari, Yudhi Anggoro

Table 1. Hospitals that have implemented Green Accounting

Hospital Name

Beth Israel Medical

JIAFR | 138
Center/Continuum Health

Partners, New York, AS.

\section{Green Accounting which is implemented}

1. The process of purchasing and procuring drugs and medical equipment

2. Cost accounting for purchasing decision

3. Cost accounting for waste management

4. Environmental accounting practices

Catholic Healthcare

West/Dominican Santa

Cruz Hospital, Nortthen

California, AS.

1. Purchasing practices and cost accounting (standardized products set by the Procurement Board)

2. Cost accounting for waste (three categories: solid waste, medical waste, toxic waste)

3. Environmental accounting practices

\section{Contra Costa Regional}

Medical Center, Martinez,

California, AS.
1. Practical buying

2. Cost accounting for purchasing decisions (historical cost, clinical effectiveness, holding costs and waste costs)

3. Cost accounting for waste management

Dartmounth Hitchcock

Medical Center, Lebanon.

1. Procurement practices

2. Cost accounting for waste (infected waste, pathology waste, chemotherapy waste, radiological waste)

3. Environmental accounting practices (incinerator, mercury waste handling)

1. Cost accounting for purchasing decisions (saving costs, expiration costs, clinical effectiveness)

2. Cost accounting for waste management (waste sorting costs)

Source: Marina, et., al, (2017)

\section{Research Methods}

This research was conducted at the Public Hospitals in Malang Raya with a descriptive quantitative approach (Arikunto, 2005) to find out the green accounting implementation in Public Hospitals and the preferences of the interests of these Public Hospitals in carrying out their business operations. 
The type of data used in this study was primary data that came from respondents' answers to the previously distributed questionnaires. The questionnaire had been completed with a brief explanation of the purpose of filling out the questionnaire. The data sources of this research were primary and secondary data sources. Primary data obtained from the answers of questionnaires from respondents directly which were sent to the accountants of each Public Hospital in Malang Raya. Meanwhile, secondary data in this research were in the form of data or documents needed to answer research questions/problems.

The population in this study were 40 Public Hospitals (RSUs) in Malang Raya, which were spread across Malang District, Malang City and Batu City. The samples of this research were 37 Public Hospitals consisting of 20 Public Hospitals in Malang District, 12 Public Hospitals in Malang City and 5 Public Hospitals in Batu City. The number of samples is in accordance with the provisions of Cohen et al. (2007: 101), Baley and Gay in Mahmud (2011: 159) who state that the minimum sample size in a study contains 30 subjects. The sample selection used probability sampling by sending a questionnaire to the entire population of Public Hospitals in Malang Raya and the questionnaires that were returned were the research samples.

Green Accounting is defined as the existence of company activities related to financial, social and environmental activities that are reported in the form of integrated, complete and relevant accounting information in the form of green accounting reporting which is useful for users in assessing economic and non-economic decision making as a form of corporate responsibility for the economy (profit), society (people) and the environment (planet). Meanwhile, interest preference is used to measure and find out which components that are the top priority of the hospital in running its business.

The implementations of green accounting in Public Hospitals considered economic/financial, social and environmental activities. Indicators used in measuring the green accounting implementation in the financial aspects included: financial reporting and financial statement audits. The social aspects included: corporate social responsibility, social activity reporting, and 
social audits. The environmental aspects included: attention to the environment, involvement in environmental issues, responsibility for the environment, reporting of environmental problems and environmental audits. These indicators were measured on a Likert scale 1-6 with the following conditions, namely: number 1 = strongly disagree, 2 = disagree, $3=$ disagree, 4 = quite agree, 5 = agree, and $6=$ strongly agree.

Interest preference is used to determine which components that are the top priority of a general hospital in running its business. Measuring was done by sorting from priority 1 to 6 for each preference of interests in running the business, including turnover/sales, profit/profit, low business costs, quality of services/products, environmentally friendly services/products, and waste that does not pollute the environment.

The questionnaires obtained were scored to test the validity and reliability, then calculated the weighted average value of each statement item contained in the questionnaire. Interpretation values were be described through words or sentences, which were separated by categories to obtain conclusions from the survey to serve as the basis for interpreting the implementation of green accounting in Public Hospitals as a descriptive analysis. Therefore, conclusions could be drawn from the results of the analysis and then used as a basis for providing suggestions and research implications. Making categories was carried out using the three-box method index number analysis (Ferdinand, 2006) by dividing the respondents' answers into 3 categories, namely numbers 1-2 = low, meaning they did not implement the green accounting, 3-4 = moderate, meaning that they haven't implemented green accounting consistently, 5-6 = high, meaning that they have implemented green accounting properly and consistently.

\section{Results and Discussion}

\section{Instrument Testing Results}

The variable of green accounting implementation used in this study showed that the 31 (thirty-one) indicators/instruments used had a Sig. value 
$<0.05$ so that the indicators used are declared as valid, and for the results of the Cronbach`s Alpha value showed a value of $0.947>0.60$ which indicates that all instruments used in this study are reliable.

\section{Descriptive Respondents}

JIAFR | 141

The number of respondents in the study were 37 (thirty-seven) Public Hospitals (RSUs) from 40 (forty) RSUs located in Malang District as many as 22 RSUs, in Malang City as many as 13 RSUs, and in Batu City as many as 5 RSUs. Of these, there were 1 RSU type A, 8 RSUs type B, 13 RSUs type C and 18 RSUs type D.

Meanwhile, the characteristics of respondents who fill in were predominantly female, with 24 people and 13 men. Twenty-six (26) respondents have an understanding in the accounting field, and 11 respondents in the management field with education levels of D3 (9 people), S1 (23 people) and S2 (5 people). In addition, respondents have had a long working period at the hospital and they are from the positions of Director of Finance and Accounting (3 people), Manager/Head of Division (11 people), Accounting and Finance Staff (21 people) and Internal Supervisory Unit/SPI (2 people). This shows that the respondents are qualified in terms of understanding in the green accounting implementation in Public Hospitals at Malang Raya.

Table 2. Respondents Data

\begin{tabular}{lccccc}
\hline \multicolumn{1}{c}{$\begin{array}{c}\text { Region / Location } \\
\text { Public Hospitals }\end{array}$} & A & B & C & D & Amount \\
Respondents
\end{tabular}

Source: Primary Data, Processed by Researchers WPS Office, 2020 
Muhammad Hasyim Ashari, Yudhi Anggoro

Table 3. Characteristics of Respondents

\begin{tabular}{|c|c|c|}
\hline Characterist & Amount & Percentage (\%) \\
\hline \multicolumn{3}{|l|}{ Gender } \\
\hline Female & 24 & 64,86 \\
\hline Male & 13 & 35,14 \\
\hline Total Gender & 37 & 100,00 \\
\hline \multicolumn{3}{|l|}{ Education Level } \\
\hline S2 & 5 & 13,51 \\
\hline S1 & 23 & 62,16 \\
\hline D3 - Diploma 3 & 9 & 24,33 \\
\hline Total Education Level & 37 & 100,00 \\
\hline \multicolumn{3}{|l|}{ Education Sector } \\
\hline Accounting & 26 & 70,27 \\
\hline Management & 11 & 29,73 \\
\hline Total Education Sector & 37 & 100,00 \\
\hline \multicolumn{3}{|l|}{ Age } \\
\hline$>23-30$ year & 13 & 35,14 \\
\hline$>30-45$ year & 19 & 51,35 \\
\hline$>45$ year & 5 & 13,51 \\
\hline Total Age & 37 & 100,00 \\
\hline \multicolumn{3}{|l|}{ Service Period } \\
\hline$>1-3$ year & 13 & 35,14 \\
\hline$>3-6$ year & 13 & 35,14 \\
\hline$>6-15$ year & 11 & 29,72 \\
\hline Total Service Period & 37 & 100,00 \\
\hline \multicolumn{3}{|l|}{ Position } \\
\hline Director of Finance and Accounting & 3 & 8,11 \\
\hline Manager or Head of Division & 11 & 29,73 \\
\hline Accounting and Finance Staff & 21 & 56,76 \\
\hline SPI (Internal Supervisory Unit) & 2 & 5,40 \\
\hline Total Position & 37 & 100,00 \\
\hline
\end{tabular}

Source: Primary Data, Processed by Researchers WPS Office, 2020 
How is the implementation of green accounting ...

\section{Analysis of Variable Description}

The green accounting implementation in Public Hospitals in Malang Raya was studied with 31 question indicators from 10 dimensions related to financial, social and environmental aspects.

JIAFR | 143

Based on the results of the descriptive analysis in the table above, it is found that 37 Public Hospitals (RSU) in Malang Raya, in the green accounting implementation from a financial aspect, have conducted financial reporting (mean $=5.03$ ) and periodic audits of financial reports (mean $=4.89$ ) as indicated by an average value (mean) of 4.96. While the green accounting implementation from the social aspect has an average value (mean) of 4.96, because the Public Hospitals in Malang Raya, according to respondents, have carried out social responsibility towards the community around the Public Hospitals (mean $=5.20$ ), and it is proven by social activity reporting (mean $=4.74$ ) and periodic social activity audits (mean $=4.95$ ). This shows that the hospitals in Malang Raya have carried out social responsibility to the community around the hospitals and periodically report and audit their social activities.

Meanwhile, from the environmental aspect, it has an average value (mean) of 4.94. This value is a reflection of the actions of the Public Hospitals in Malang Raya which have paid attention to the environment (mean $=5.22$ ), have involved in environmental issues (mean $=4.92$ ), have been responsible for environmental problems (mean $=4.79$ ), have given reports against environmental problems (mean $=4.86$ ), as well as conducting environmental audits periodically (mean $=4.86$ ). The most dominant thing seen in this environmental aspect is the hospital's attention to environmental problems with the involvement of management and it is evidenced by the existence of environmental problems reporting and environmental audits periodically. This shows the form of responsibility for Public Hospitals in Malang Raya towards environmental problems.

Thus, it can be concluded that the implementation of green accounting in Public Hospitals in Malang Raya in terms of financial activities, social activities 
and environmental activities shows an average value (mean) of 4.95. It means that based on the three-box method index is at a value between 4 and 5 (medium and high), which is close to the value of 5 (high), and this is also supported by the median and mode values which are at the value of 5-6 (high category). Therefore, the implementation of green accounting has actually been implemented properly and consistently, but unfortunately not all Public Hospitals in Malang Raya implement green accounting in their business operations.

This can be seen in the average results (mean) of 37 respondents who gave an assessment that there were 20 Public Hospitals in Malang Raya or as many as $54.06 \%$ were in moderate criteria. It means that these Public Hospitals have not implemented green accounting consistently, whereas 17 Public Hospitals in Malang Raya or as many as $45.94 \%$ were in high criteria, which means that the Public Hospitals have implemented green accounting properly and consistently.

Table 4. Descriptive Analysis of Green Accounting Implementation Variables

\begin{tabular}{|c|c|c|c|c|}
\hline No & Description & Mean & Median & Mode \\
\hline \multicolumn{2}{|c|}{ FINANCIAL ASPECT } & 4.96 & & \\
\hline \multicolumn{2}{|c|}{ Finance Report } & 5.03 & & \\
\hline 1 & $\begin{array}{l}\text { The hospital clearly identifies each } \\
\text { component of the financial statements, } \\
\text { including transactions related to social and } \\
\text { environmental activities }\end{array}$ & 5.03 & 5 & 5 \\
\hline \multicolumn{2}{|c|}{ Financial Report Audit } & 4.89 & & \\
\hline 2 & $\begin{array}{l}\text { The hospital conducts regular annual audits } \\
\text { of financial reports }\end{array}$ & 4.89 & 5 & 5 \\
\hline \multicolumn{2}{|c|}{ SOCIAL ASPECT } & 4.96 & & \\
\hline \multicolumn{2}{|c|}{ Hospital Social Responsibility } & 5.20 & & \\
\hline 3 & $\begin{array}{l}\text { The social activities carried out by the } \\
\text { hospital do not cause a decrease in the } \\
\text { quality of services }\end{array}$ & 5.11 & 5 & 5 \\
\hline 4 & The hospital always strives to maintain the & 5.32 & 5 & 5 \\
\hline
\end{tabular}


How is the implementation of green accounting ...

\begin{tabular}{|c|c|c|c|c|}
\hline No & Description & Mean & Median & Mode \\
\hline & security of the services provided & & & \\
\hline 5 & $\begin{array}{l}\text { Hospital makes innovations in services } \\
\text { according to consumer expectations }\end{array}$ & 5.38 & 5 & 5 \\
\hline 6 & $\begin{array}{l}\text { The hospital provides accurate and reliable } \\
\text { information to the public }\end{array}$ & 5.43 & 5 & 5 \\
\hline 7 & $\begin{array}{l}\text { Social activities carried out by the hospital } \\
\text { do not impose prices on services }\end{array}$ & 5.05 & 5 & 5 \\
\hline 8 & $\begin{array}{l}\text { The hospital is concerned about the future } \\
\text { of its employees }\end{array}$ & 5.00 & 5 & 5 \\
\hline 9 & $\begin{array}{l}\text { The hospital is able to provide a sense of } \\
\text { security to its employees }\end{array}$ & 4.97 & 5 & 5 \\
\hline 10 & $\begin{array}{l}\text { The hospital actively participates in social } \\
\text { activities }\end{array}$ & 5.16 & 5 & 5 \\
\hline 11 & $\begin{array}{l}\text { The hospital is responsible for the waste } \\
\text { generated }\end{array}$ & 5.46 & 6 & 6 \\
\hline 12 & $\begin{array}{l}\text { The hospital makes a policy regarding the } \\
\text { services produced must be } \\
\text { environmentally friendly }\end{array}$ & 5.14 & 5 & 5 \\
\hline \multicolumn{2}{|c|}{ Social Activity Reporting } & 4.74 & & \\
\hline 13 & $\begin{array}{l}\text { The hospital presents reports on social } \\
\text { activities as a form of responsibility for the } \\
\text { hospital to the surrounding community }\end{array}$ & 4.51 & 5 & 5 \\
\hline 14 & $\begin{array}{l}\text { The hospital presents social costs in } \\
\text { financial reports }\end{array}$ & 4.97 & 5 & 5 \\
\hline \multicolumn{2}{|c|}{ Social Audit } & 4.95 & & \\
\hline 15 & The hospital conducts regular social audits & 4.95 & 5 & 5 \\
\hline \multicolumn{2}{|c|}{ ENVIRONMENTAL ASPECT } & 4.94 & & \\
\hline \multicolumn{2}{|c|}{ Environmental Attention } & 5.22 & & \\
\hline 16 & $\begin{array}{l}\text { There are regulations regarding the } \\
\text { environment which are used as the basis } \\
\text { for hospital in environmental problems }\end{array}$ & 5.22 & 5 & 5 \\
\hline 17 & $\begin{array}{l}\text { There is management concern that the } \\
\text { environment is important to be maintained }\end{array}$ & 5.22 & 5 & 5 \\
\hline \multicolumn{2}{|r|}{$\begin{array}{l}\text { Management Involvement in Environmental } \\
\text { Issues }\end{array}$} & 4.92 & & \\
\hline 18 & $\begin{array}{l}\text { Inside the hospital, there is a unit that } \\
\text { deals with environmental issues }\end{array}$ & 5.03 & 5 & 5 \\
\hline
\end{tabular}

Journal of Islamic Accounting and Finance Research - Vol. 3 No. 1 (2021) 


\begin{tabular}{|c|c|c|c|c|}
\hline No & Description & Mean & Median & Mode \\
\hline 19 & $\begin{array}{l}\text { There is a budget for environmental } \\
\text { protection }\end{array}$ & 4.97 & 5 & 5 \\
\hline 20 & $\begin{array}{l}\text { There are programs or procedures that } \\
\text { reduce the consumption of natural } \\
\text { resources in order to be economical }\end{array}$ & 4.76 & 5 & 5 \\
\hline \multicolumn{2}{|c|}{ Environmental Responsibility } & 4.79 & & \\
\hline 21 & $\begin{array}{l}\text { The hospital has the availability of } \\
\text { sufficient human and economic resources } \\
\text { to be environmentally responsible }\end{array}$ & 4.76 & 5 & 5 \\
\hline 22 & $\begin{array}{l}\text { There are efforts to deal with hospital } \\
\text { waste }\end{array}$ & 5.35 & 5 & 5 \\
\hline 23 & $\begin{array}{l}\text { There is a hospital policy in dealing with } \\
\text { waste even though the hospital is } \\
\text { experiencing a loss }\end{array}$ & 5.03 & 5 & 5 \\
\hline 24 & $\begin{array}{l}\text { There is a hospital policy in dealing with } \\
\text { waste even though the hospital has to } \\
\text { close its business }\end{array}$ & 4.03 & 5 & 5 \\
\hline \multicolumn{2}{|c|}{ Environmental Problem Reporting } & 4.89 & & \\
\hline 25 & $\begin{array}{l}\text { The hospital reports on the use of natural } \\
\text { resources and their impact on the } \\
\text { environment }\end{array}$ & 5.03 & 5 & 5 \\
\hline 26 & $\begin{array}{l}\text { The hospital presents the cost of waste } \\
\text { treatment in financial reports }\end{array}$ & 4.97 & 5 & 5 \\
\hline 27 & $\begin{array}{l}\text { Environmental performance reports are } \\
\text { reported on an ongoing basis }\end{array}$ & 5.08 & 5 & 5 \\
\hline 28 & $\begin{array}{l}\text { Environmental performance reports are } \\
\text { published for the public to know }\end{array}$ & 4.49 & 5 & 5 \\
\hline \multicolumn{2}{|c|}{ Environmental Audit } & 4.86 & & \\
\hline 29 & $\begin{array}{l}\text { There is a systematic and documented } \\
\text { verification process in the environmental } \\
\text { audit process }\end{array}$ & 4.84 & 5 & 5 \\
\hline 30 & $\begin{array}{l}\text { There is an internal supervisor who } \\
\text { conducts environmental audits }\end{array}$ & 4.84 & 5 & 5 \\
\hline 31 & $\begin{array}{l}\text { The hospital conducts regular } \\
\text { environmental audits }\end{array}$ & 4.92 & 5 & 5 \\
\hline
\end{tabular}

Source: Primary Data, Processed by Researchers WPS Office, 2020 
How is the implementation of green accounting ...

Table 5. Respondents' Average Rating based on the Three Box Method Index

\begin{tabular}{|c|c|c|c|}
\hline Criteria & Assessment & Frequency & Percentage \\
\hline & 1 & 0 & $0 \%$ \\
\hline \multirow[t]{2}{*}{ Low } & 2 & 0 & $0 \%$ \\
\hline & 3 & 2 & $5.41 \%$ \\
\hline \multirow[t]{2}{*}{ Moderate } & 4 & 18 & $48.65 \%$ \\
\hline & 5 & 16 & $43.24 \%$ \\
\hline High & 6 & 1 & $2.70 \%$ \\
\hline \multicolumn{2}{|c|}{ Amount } & 37 & $100.00 \%$ \\
\hline
\end{tabular}

Source: Primary Data, Processed by Researchers WPS Office, 2020

\section{Interest Preference}

Interest preference as the main priority of Public Hospitals in Malang Raya in running their business was measured by ranking priority from 1 to 6 for each preference of interests such as turnover/sales, profit, low business costs, quality of services/products, environmentally friendly services/products, and waste that does not pollute the environment.

The results show that Public Hospitals in Malang Raya prioritize Public Hospitals in carrying out their business operations so the waste generated does not pollute the environment. As many as 20 out of 37 respondents (54.05\%) chose this as the main objective in running their business operations. Furthermore, 19 out of 37 respondents (51.35\%) chose service quality as the main priority in running hospital operations. Of the 37 respondents, 15 respondents (40.54\%) chose to run the business with low business cost. The aim was that the community could get services evenly. Furthermore, 12 out of 37 respondents gave priority to environmentally friendly services $(32.43 \%)$. As many as 11 respondents from 37 respondents (29.73\%) prioritize hospital profits and as many as 9 out of 37 respondents (24.32\%) prioritize turnover in running the hospital business.

Thus, it can be concluded that in carrying out its business, the Public Hospitals in Malang Raya prioritize that the waste produced does not pollute the environment and they can maintain good service quality by considering services with low business costs so that it is affordable by the surrounding 
community. Therefore, the services provided must environmentally friendly so that profits can still be obtained even though sales turnover is not a top priority.

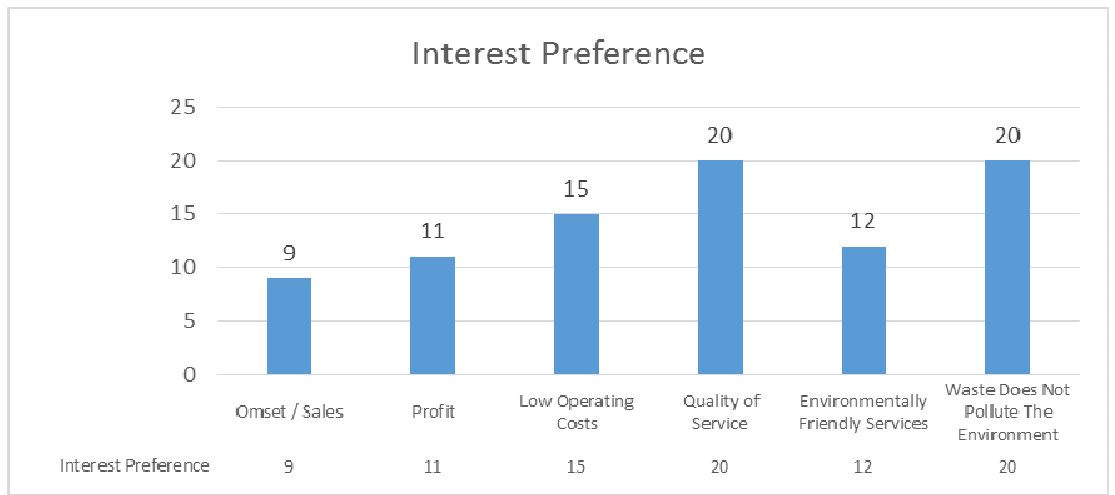

Figure 1. Interest Preference Graph

\section{Conclusion}

Based on the results and discussion in this study, it can be concluded that the green accounting practices in Public Hospitals in Malang Raya based on financial activities, social activities and environmental activities has been implemented properly and consistently. This is indicated by the mean value, median and mode that are in the high category based on the three-box method index. However, in the green accounting implementation, only $45.94 \%$ that actually did it well and consistently, the rest still have not implemented green accounting consistently. With the awareness of Public Hospitals in Malang Raya to green accounting implementation in the accountability of their business activities, it can have an impact, especially on environmental sustainability and the welfare of the community around the Public Hospitals from the impact of the resulting waste. Of course, for Public Hospitals that have not implemented green accounting properly and consistently and that are improving it to implement it properly and consistently, it will then be maintained in its implementation. Therefore, it is necessary to have regulations that certainly regulate and determine the 
format, model and form of green accounting reporting. For this reason, the Indonesian Accountants Association (IAI - Ikatan Akuntansi Indonesia) can take on this role by issuing a Green Accounting Standard.

This study does not make any differences in the green accounting implementation based on the class (type) of the hospital so that it cannot JIAFR | 149 know the green accounting implementation in each of these classes. In addition, respondents who filled out the research questionnaire had differences in the level of position, tenure, education level and age which of course would result in differences in understanding of the green accounting implementation in Public Hospitals in Malang Raya. Further research can conduct a study of all Public Hospitals in Indonesia in terms of the green accounting implementation at these Public Hospitals. In addition, it can conduct research to compare the green accounting implementation based on the class (type) of the hospital and conduct a study of the effect of the green accounting implementation on the sustainability of the hospital's business, and analyze the factors that influence the hospital to implement green accounting in its activities.

\section{References}

Aminah \& Noviani. (2014). Analisis Penerapan Akuntansi Lingkungan di Rumah Sakit Mardi Waluyo Metro. Jurnal Akuntansi \& Keuangan. September 2014, 5(2), 1-16.

Arikunto, S. (2005). Prosedur Penelitian: Suatu Pendekatan Penelitian. Jakarta: Rineka Cipta.

Arizona, I. P. E., \& I. W. Suarjana. (2017). Kepedulian dan Pengetahuan Pelaku Bisnis mengenai Green Accounting. Jurnal Riset Akuntansi (JUARA). September 2017. 7(2), 157-166.

Astiti, W. (2014). Implementasi Green Accounting berbasis University Social Responsibility (USR) di Universitas Negeri Yogyakarta. Jurnal Nominal, 3(2), 134-149.

Astuti, N. (2012). Mengenal Green Accounting. Jurnal PERMANA. August 2012. 4(1), 69-75. 
Muhammad Hasyim Ashari, Yudhi Anggoro

Beattie, A. (2017). The 3 pillars of corporate sustainability. Investopedia.com, December 15, 2017 https://www.investopedia.com/articles/investing/100515/threepillars-corporate-sustainability.asp.

JIAFR | 150 Burhany, D. I. (2015). Akuntansi Manajemen Lingkungan sebagai Alat Bantu untuk Meningkatkan Kinerja Lingkungan dalam Pembangunan Berkelanjutan. Indonesian Journal of Economics and Business. 1(2), 257-270.

Chahal, H., \& R. D. Sharma, (2006). Implications of Corporate Social Responsibility on Marketing Performance: A Conceptual Framework. Journal of Services Research, April 2006 - September 2006, 6(1), 215-228.

Cohen, L., L. Manion, \& K. Morrison. (2007). Research Methods in Education. Sixth Edition. New York: Routledge.

Deegan, C. (2003). Environmental Management Accounting: An Introduction and Case Studies for Australia, Victoria. Environment Protection Authority. Institute of Chartered Accountants in Australia.

Dhiman, S. (2008). Product, People, Planet: The Triple Bottom Line Sustainability Imperative. Journal of Global Business. 2(2), 51-57.

Dunk, A. S. (2002). Product Quality, Environmental Accounting and Quality Performance. Accounting, Auditing \& Accountability Journal. MCB Up Limited. 15(5), 719-732.

Elkington, J. (1997). Cannibals with Forks-Triple Bottom Line of 21 Century Business. Stoney Creek, CT: New Society Publishers.

Elkington, J. (2001). The Chrysalis Economy: How Citizen CEOs and Corporations can Fuse Values and Value Creation. Capstone Publishing Ltd. United Kingdom.

Ferdinand, A. (2006). Metode Penelitian Manajemen: Pedoman Penelitian untuk Skripsi, Tesis dan Disertasi Ilmu Manajemen. Semarang: Universitas Diponegoro.

Gallhofer, S., \& J. Haslam. (1997). The Direction of Green Accounting Policy: Critical Reflections. Accounting, Auditing, \& Accountability Journal. 10(2), 148-174.

Hadi, N. (2014). Corporate Social Responsibility. Yogyakarta: Graha Ilmu. 
How is the implementation of green accounting ...

Hansen, D. R., \& M. M. Mowen. (2009). Akuntansi Managerial. Jakarta: Salemba Empat.

Hati, R. P. (2018). Analisis Penerapan Green Accounting Berbasis University Social Responsibility (USR) pada Universitas Riau Kepulauan dan Universitas Internasional Batam. Measurement Journal.12(1), 121-131.

International Organization for Standarization (ISO) series 14010-14019 about Environmental Auditing (Audit Lingkungan).

Khoirina, M. M. (2016). Analysis of Green Accounting to Support Corporate Social Responsibility (Case Study: Semen Gresik Hospital). Jurnal Akuntansi AKRUAL. 8(1), 1-10.

Lako, A. (2015a). Berkas CSR bukan Fiksi. Edisi Pertama. La Tofi Publishing Enterprises. Lako, A. (2015b). CSR Investasi Strategis. Investor Daily. 18 May 2015.

Lako, A. (2016). Transfromasi Menuju Akuntansi Hijau. CPA Indonesia. Edisi 7.p. 52-54.

Lako, A. (2018). Akuntansi Hijau: Isu, Teori dan Aplikasi. Jakarta: Salemba Empat. Mahmud. (2011). Metode Penelitian Pendidikan. Bandung: Pustaka Setia.

Marina, A., S. I. Wahjono, \& G. Desipradani. (2017). Akuntansi Hijau Berbasis Etika Bisnis: Implementasi di RSUA Ponorogo, Jawa Timur. Jurnal Balance. 16(1), 19-28.

Panggabean, R. R., \& H. Deviarti. (2012). Evaluasi Pengungkapan Akuntansi Lingkungan dalam Perspektif PT Timah (Persero) Tbk. Binus Business Review. 3(2), 1010-1028.

Pernyataan Standar Akuntansi Keuangan No.1 (Revisi 2009). 2009. Ikatan Akuntansi Indonesia.

Porter, M.E. \& Kramer, M.R. (2002). The Competitive Advantage of Corporate Philanthropy. Harvard Business Review. December 2002, 1-15.

Putri, C. F., D. Purnomo \& E. Astuti. (2016). Analisis Kesiapan Rumah Sakit Menuju Ramah Lingkungan (Green Hospital) di Kota Malang. Seminar Nasional Inovasi dan Aplikasi Teknologi di Industri (SENIATI) 2016. Institut Teknologi Nasional Malang. p. 12-17. 
Muhammad Hasyim Ashari, Yudhi Anggoro

Puspitaningtyas, Z. (2016). Mengakuntasikan Corporate Social Responsibility: Pengukuran dan Penyajian Biaya Sosial dalam Laporan Keuangan. Prosiding Seri Ekonomi Konferensi Nasional PkM CSR ke-2. Tangerang: Lembaga Penelitian dan Pengabdian kepada Masyarakat Universitas Pelita Harapan. 5(2), 94-103.

Prasetyo, H., Indriani, I., \& Widodo, A. (2020). Comparative study on the application of green accounting based on university social responsibility at Universities in Pontianak.Journal of Islamic Accounting and Finance Research, 2(2), 185-208. doi:http://dx.doi.org/10.21580/jiafr.2020.2.2.6316.

Reller, A. (2012). Greener Hospitals. Germany: Environment Science Center.

Quinn, L., \& J. Baltes. (2007). Leadership and The Triple Bottom Line Bringing Sustainability and Corporate Social Responsibility to Life. Center for Creative Leadership Research Whitepaper. 1-13.

Setiawan, T. (2014). Penerapan Akuntansi Manajemen Lingkungan pada Dua Puluh Lima Perusahaan yang Terdaftar di Indeks SRI KEHATI 2013. Jurnal Akuntansi. 2, 110-129.

Shapiro, K., M. Stoughton., R. Graff., \& L. Feng. (2000). Healthy Hospitals: Environmental Improvements through Environmental Accounting. Boston: Tellus Institute.

Suaryana, A. (2011). Implementasi Akuntansi Sosial dan Lingkungan di Indonesia. Jurnal Ilmiah Akuntansi dan Bisnis. 6(1), 1-26.

Susilo, J. (2008). Green Accounting di daerah Istimewa Yogjakarta: Studi Kasus antara Kabupaten Sleman dan Kabupaten Bantul. JAAI. 12(2), 149-165.

Swastyakso, B. G., \& H. Y. S. Widodo. (2016). Penerapan Akuntansi Manajemen Lingkungan pada Rumah Sakit di Yogyakarta. Jurnal Universitas Atma Jaya, 1-11.

Thornton, D.B. (2013). Green Accounting and Green Eyeshades Twenty Years Later. Critical Perspective on Accounting. 24, 438442.

Wardah, S., \& Y. Astini. (2018). Pemahaman Manajemen Rumah Sakit tentang Pentingnya Kinerja Lingkungan dalam Pembangunan Berkelanjutan. Valid Jurnal Ilmiah. 15(2), 99-111. 
How is the implementation of green accounting ...

Wibisono, Y. (2007). Membedah Konsep \& Aplikasi CSR (Corporate Social Responsibility). Jakarta: Gramedia.

Yakhou, M., \& P. D. Vernon. (2004). Environmental Accounting: An Essential Component of Business Strategy. Journal of Business Strategy and the Environment. 13(2), 65-77.

Yousef, F. H. (2003). Green Accounting in Developing Countries: The Case of UAE and Jordan. Manajerial Finance. 29(8), 37-45.

Zakiy, F. S., \& Ramadhan, D. S. (2019). Socialize the Ilahiyah Doctrine on Corporate Social Responsibility in the Modern Business. KHATULISTIWA: Journal of Islamic Studies, 9(2), 112-125.

Zvezdov, D. (2012). Rolling out Corporate Sustainability Accounting: A Set of Challenges. Journal of Environmental Sustainability. 2.(2). 
JIAFR | 154 